\title{
Higher Education and the marketization of compulsory schooling: English Universities and academy sponsorship.
}

\author{
Nadia Edmond*
}

Faculty of Education, University of Brighton, UK

\begin{abstract}
Recent policy emphasis on market mechanisms to drive up the performance of education systems has resulted in rising fees and increased competition in Higher Education (HE) in England, and in the creation of different types of self-governing state funded schools run independently of municipal authority in compulsory schooling. University sponsorship of Charter Schools in the US raises issues which this article examines in relation to university sponsorship of academies in England. The article provides a quantitative overview of university sponsorship of academies over the last decade and explores how the policy context has shaped the discursive construction of sponsorship by the institutions concerned. Different patterns of sponsorship linked to institutional position and differentiated discourses of 'sponsorship' consistent with 'academic entrepreneurship' are identified. The discursive function of sponsorship is argued to extend to a legitimation of the policy itself reflected in increasing government pressure on universities to sponsor academies.
\end{abstract}

Keywords: charter schools; academy schools; university sponsors; academic entrepreneurship; English education policy

\section{Introduction}

Global neoliberal policy has been characterised by the subjugation of the public sector to the 'discipline of the market' (Ferlie, Lynn, \& Pollitt, 2005). In all phases of education, this has resulted in increasing privatisation (see for example Ball, 2007; Mansell \& Johnson, 2014) and the promotion of a business ethos (see for example Natale, Libertella, \& Hayward, 2001).

For schools, a manifestation of this has been privately run state funded schools. These were introduced in the US, in the early 1990s, in New Zealand and more recently Australia (as 'Charter Schools'), in Sweden (as 'Free Schools'), Chile (as 'Corporate Schools') and in England 'academies' were introduced in 2000. Though state funded, these schools' independence of existing local government has required the development of new structures. In the US, Charter Schools are established by a charter (contract) between a school and an 'authorizer', a legal entity that awards the 'charter', sets expectations and oversees school performance (Shen, 2011). In England, academies are overseen by individual charitable bodies ('academy trusts') and may be part of a Multi-Academy Trust (MAT) in which several schools are run by a single trust (DfE, 2016a).

The key characteristics of academies are that, like the schools they replace, they provide non-fee paying education for the local community but unlike them, operate as separate legal

\footnotetext{
*Email: n.edmond@brighton.ac.uk
} 
entities which contract with, and are funded directly by, central government, notably the Department for Education (DfE). They are not required to follow the national curriculum ${ }^{i}$ and can set different terms and conditions of employment including length of school day and term times, freedoms not available to other state-funded schools (Bayliss, 2016).

Though university faculties of education have long had links with local schools, notably to provide student teachers with classroom experience, few have been involved in the running of schools (exceptions are the small number of 'laboratory' schools in the US (Kennedy, 2016) or 'model' schools operating in Finland and Japan (OECD, 2010). Notwithstanding the new opportunities for university involvement in public schooling, the phenomenon of university involvement in privately run/publicly funded schools has been little researched. Despite US Charter Schools' longer history, there has been little research undertaken (Bergeron, 2015; Eckes, 2013) and a search of the British Education Index yielded no peer reviewed articles with this focus. This article seeks to make an original contribution to this limited literature.

\section{Issues raised in the US experience of HE sponsorship of Charter Schools}

Both charter school authorizers in the US and academy trust sponsors in the UK have legal responsibility for the quality of education in their schools, both receive public funds to carry out their role, and the US literature raises a number of issues pertinent to a consideration of the role of universities in academies in the UK.

The Charter Schools policy has been greatly contested, a key voice in the debate being that of Diane Ravitch (2010, 2014, 2016) who has argued that the diagnosis of public school failure is wrong, and the solutions, including charter schools, of the corporate reformers are wrong. In the context of that debate, it has been suggested that HE institutions are natural choices as authorizers because they have a stake in ensuring quality education and most authorizing Higher Education Institutions (HEIs) saw it as part of their overall mission to improve education and as an opportunity to use their expert knowledge (Shen, 2011). It is also significant that the public perception of universities raises levels of public support when schools are university authorized (Reckhow, Grossman, \& Evans, 2015).

Opposition to university sponsorship in the US has drawn on concerns that it would 'strip the democracy out of the process, by placing authorization in the hands of college officials who aren't held accountable directly to taxpayers' (Lindstrom, 2014) and that HEIs do not have the existing infrastructure, specific knowledge of the day-to-day functioning of schools or capacity for authorizing responsibilities (Shen, 2011).

In fact, only 13 states allow university authorizers and few HEIs have come forward (Lindstrom, 2014) with the proportion doing so declining between 2010 and 2015 (NACSA, 2016). This perhaps reflects the risks identified by a number of authors (see for example, (Basinger, 1999; Bergeron, 2015; Plucker et al., 2004) which can be summarised as:

- financial (the authorizing function is underfunded);

- reputational (school performance reflects badly on the institution);

- misalignment with university mission (including a lack of research connecting the charter school with the university).

In addition, involvement in charter schools may jeopardize the university's work in traditional public schools (Finn, Ryan, \& Rafferty, 2010). 


\section{The English education policy context}

Ball (2007) has noted a global convergence in education policy giving rise to

a generic global policy ensemble that rests on a set of basic and common policy technologies ... the market, management and performativity [based on] ... the increasing colonisation of education policy by economic policy imperatives. (p. 39, emphases in the original)

Schools in England have been subject to these policy technologies with the academies programme particularly geared to promoting marketization and privatisation. The Learning and Skills Act 2000 which introduced 'City Academies', modelled on the previous Conservative government's 'City Technology Colleges' and US 'Charter Schools', was a significant step in the 'creeping privatisation' of education (Gillard, 2011) whereby 'failing' schools were transferred from the Local Authority (LA) to private sponsors (individuals or organisations required to contribute $£ 2 \mathrm{M}$ to the project).

The following decade saw attempts to broaden the scope of this privatisation to all schools. The Education and Inspection Act 2006 proposed that all primary and secondary schools be encouraged to become independent state schools ('trust schools') though few schools did (Helm \& Lightfoot, 2007) and it was the Coalition government's Academies Act 2010 which continued and significantly extended the policy by enabling high performing schools to 'opt out' of LA control ('converter academies') and the creation of new academy schools ('free schools').

This has resulted in complexity and fragmentation as different 'privatised' alternatives to LA schools have been introduced (West \& Bailey, 2013) and, as with Charter Schools in the US, the policy has been the focus of considerable contestation spanning a range of critiques (Gunter, 2011). The claims of academisation's positive impact on school performance have been challenged (Gorard, 2011) and there is mounting evidence that the academies programme is doing little to improve standards (see for example, Andrews, 2016). There has been concern over the status and role of private interest in publicly funded education (Gunter, 2011), claims of conflicts of interest and financial irregularities (Boffey, 2015) as well as concerns about how not-for-profit academies have been thrown open to entrepreneurial interests (Boffey \& Mansell, 2016) and the consequent distortions in the purpose of public education (Gunter, 2011). A fundamental 'democratic deficit' in sponsoring arrangements is manifest in the control of academies lying outside of public accountability, the lack of transparency in their operations, the loss of parental voice and influence, and the deleterious effect on the local community and other local schools (Hatcher, 2011).

Ball's 'policy technologies' have also been evident in HE with the introduction of league tables and metrics, the introduction of tuition fees and the removal of caps on student numbers. Tuition fees introduced in the Teaching and Higher Education Act 1998, have risen from $£ 1,000$ to a maximum of $£ 9,000$ per year with the HE Act 2010 and are set to rise further according to the Higher Education and Research Bill (2016-17) entrenching the redefinition of higher education from generic public good to individual and social economic benefit, and 'the retreat of the state from financial responsibility for it' (Collini, 2010).

This 'redefinition' has been reflected in a transformation of the university in policy documents from an institution with the breadth of purpose outlined in the Robbins report (1963) $)^{\mathrm{ii}}$ into one 'increasingly construed as a directly economic factor to be governed in conjunction with similar factors to boost economic competitiveness' (Jessop, 2017, n.p.). Thus, there has been ever increasing policy emphasis on 'employability', research 'impact' and on institutional competition for students, repositioned as consumers, between established 
institutions and, in prospect, 'new providers' (Higher Education and Research Bill, 2016-17).

A key development in universities has been the growth and institutionalisation of 'third stream' activity, i.e., revenue-raising activities undertaken alongside teaching and research. Given constraints on funding for teaching and research, this has provided a source of new income for universities and the discourse of wider social and economic impact has provided justification for a wide range of revenue generating incursions in the local economy consistent with their promotion as 'local economic agents' (see for example, the 'Leading Places Scheme’, Wade, 2017). The sponsorship of academies and UTCs (University Technical Colleges) is symptomatic of HE institutions' increasing diversification of activities in the pursuit of revenue, running parallel with their increasing stratification in terms of status and resources (Shore \& McLauchlan, 2012).

Increasing diversification and stratification has been the backdrop to, and consequence of, policy, particularly since the granting of university status to polytechnics (tertiary education institutions with a focus on applied education for professional work) in 1992 (Wakeling \& Savage, 2015). Boliver (2015) has identified a clustering of institutions, Oxford and Cambridge and most 'Old' universities forming the top two clusters are characterised by higher levels of research activity, greater wealth and more academically successful and socioeconomically advantaged student intakes. The majority of 'New' universities (mostly ex-polytechnics) are located in a third cluster with a quarter of them forming a distinctive fourth and lowest cluster. Institutional response to the policy context (including the form development of third stream activity takes) should be understood with reference to this stratification.

Against this background, policy interest in HEI sponsorship has been a feature of the history of academies. In 2007, a discursive appeal to the reputation and expertise of HEIs was made as more universities were invited to sponsor academies, and universities became exempt from the financial contribution (Lipsett, 2007) ${ }^{\mathrm{iii}}$ :

As well as sharing the strength of their reputation, in sponsoring an academy or supporting a trust school a university can share and develop its expertise in a number of key areas. (DCSF, 2007, p. 4)

Subsequently, the Academies Act 2010 introduced two specific initiatives aimed at university involvement; 'University Training Schools' (UTSs), new academies run by faculties of education, and 'University Technology Colleges' (UTCs) providing technical education for 14-19 year olds (DfE, 2010).

Nevertheless, sponsorship of schools has remained less than popular with most universities. There was a 25-fold increase in the number of academies between 2010 and 2016 to over 5,000 (DfE, 2016b) but university sponsored academies only increased from 11 to 71. This study sought to identify whether the stratified nature of English HE is reflected in the way institutions have engaged with sponsorship and to examine the institutions' discursive constructions of sponsorship with a view to locating these within the social and policy context outlined above and the associated changing discourse of $\mathrm{HE}$.

\section{Research approach}

The research focused on 23 universities identified as 'lead sponsors' of academy trusts (i.e., in a contractual arrangement with the DfE) in 2015/16. It examined publicly available data on sponsorship (DfE, 2016b; HEFCE, 2016) and undertook a critical discourse analysis (CDA) of the website texts of sponsoring universities and their trusts/schools. 
Discourse Analysis views language as an inevitably socially and historically situated social practice which, while it is socially shaped, is also socially shaping. Critical Discourse Analysis (CDA) aims to explore the relationships of causality or influence between discursive practices and social and cultural structures and their place within wider processes of social and cultural change with a focus on how such change is ideologically shaped by relations of power and struggles over power (Fairclough, 1993).

Over 25 years ago, Fairclough analysed the changing discursive practices of HE arguing that they were being transformed through the increasing salience of 'promotion' as a communicative function with implications for the professional identities of academics and the identities of institutions (Fairclough, 1993). CDA has since been the basis of much scholarship of HE, recording and analysing its changing discursive practices (see for example the review by Rogers et al., 2016) and this has included the 'identity work' of discourse for institutions (for example Saichaie \& Morphew, 2014), students (for example Edmond, 2017) and academic staff (for example Uzuner-Smith \& Englander, 2015) which have been symptomatic of and contributing to the increasing marketization of HE.

In this study, the 23 university websites were searched to find reference to their academy trust(s) or school(s). Websites/pages of the associated academy trust(s) or school(s) were also searched for reference to the sponsoring university (for MATs the trust site was used, for individual schools the school site). A total of 46 web pages and 14,736 words of text was analysed. The university and the trusts/schools' website text were treated as a single corpus as it was not possible to determine authorship (for example where the trust page was on the university website). References to sponsorship were analysed to identify commonalities, across academy trusts, in instances of the ways in which the university, the relationship between the university and its school(s) and the nature of sponsorship, were presented, to derive categories of discursive constructions. We start below with an analysis of the quantitative data.

\section{University sponsorship of academies and free schools in England: a quantitative analysis}

The number of university sponsored academies opening per year grew between 2006 and 2013, but has fallen dramatically since as shown in Figure 1.

Figure 1. Number of University sponsored academies opening per year 


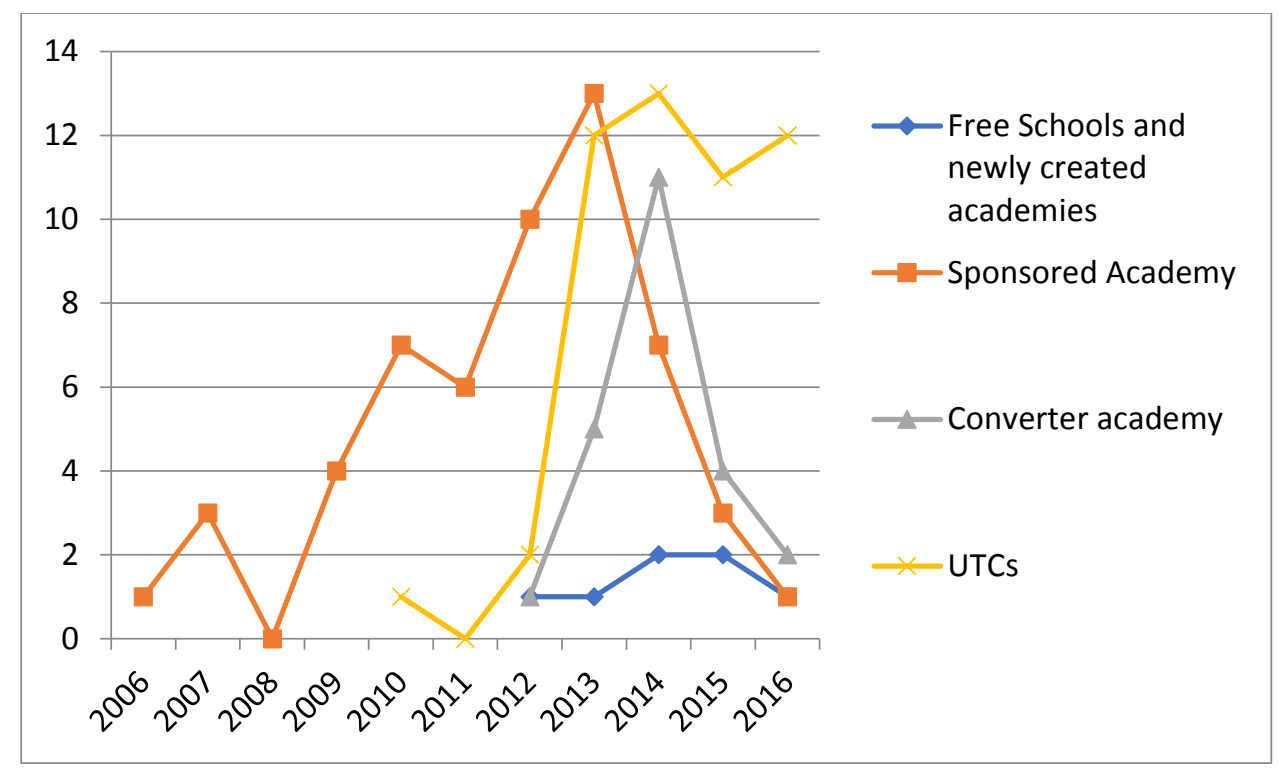

In contrast to the marked decline in the number of university sponsored academies opening, there has been a relatively steady 10 to 14 UTCs opening per year since 2013, though we might anticipate a fall here too given the closure of seven UTCs due to recruitment problems since 2015 (Weal, 2017) and Michael Gove, the Education Secretary responsible for their launch having declared them a failure (Burke, 2017).

Figure 2. Number of academies and free schools per sponsoring HEI July 2016

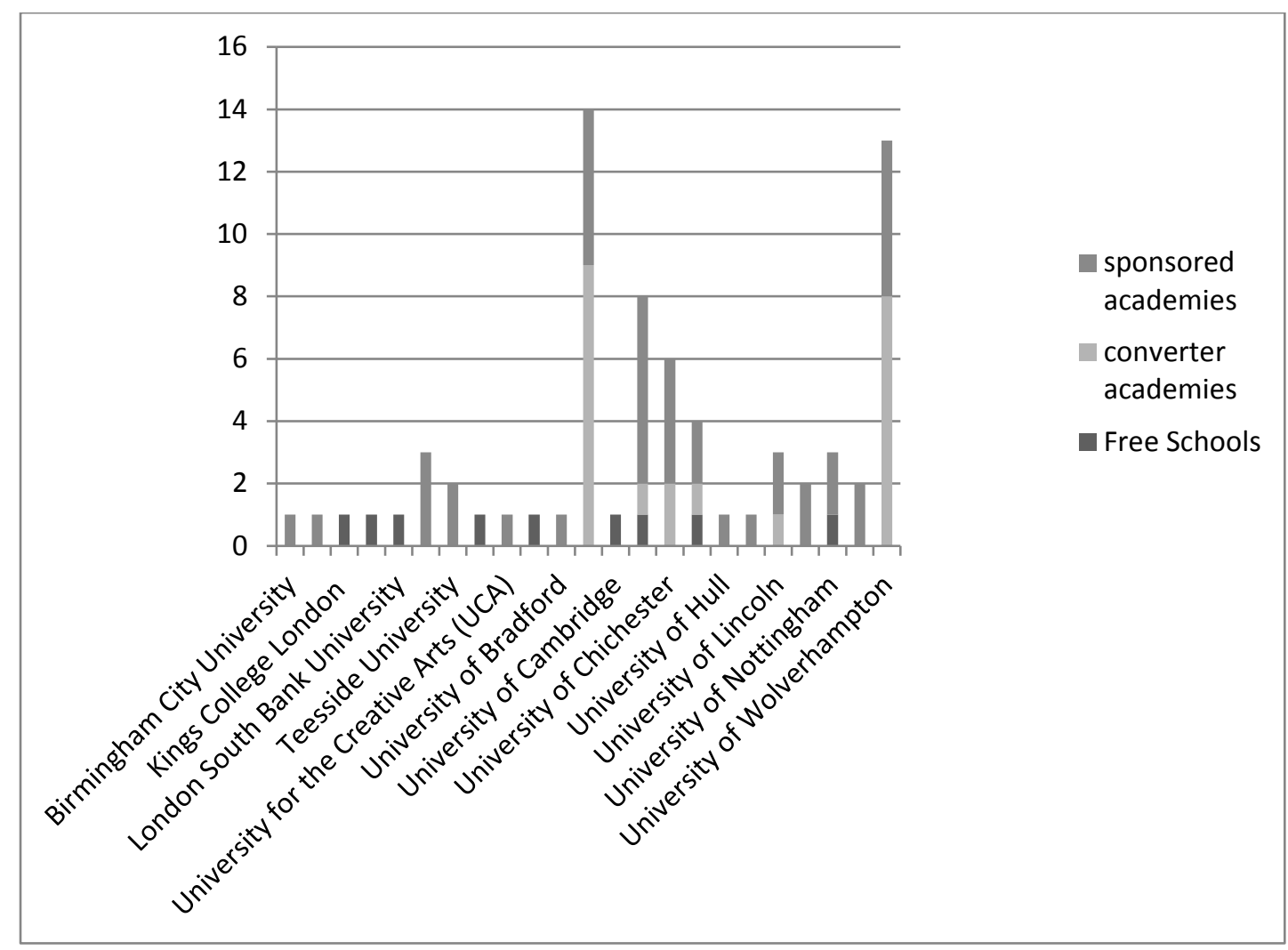


Figure 2 reveals three patterns of university sponsorship:

1. The sponsoring of one or a small number of local failing schools as 'sponsored academies';

2. The sponsoring of a single new academy;

3. The development of a MAT sponsoring a larger number of different types of academies.

Table 1, below, shows these patterns of engagement are associated with HEIs which fall in different status clusters.

Table 1. Characteristics of universities sponsoring academies

\begin{tabular}{|c|c|c|c|c|}
\hline $\begin{array}{l}\text { Universities whose engagement conforms with } \\
\text { Pattern } 1 \text { Average league table ranking = } 74\end{array}$ & $\begin{array}{l}\text { Cluster } \\
\text { Using } \\
\text { Boliver } \\
\text { (2015) } \\
\end{array}$ & $\begin{array}{l}\text { League } \\
\text { table } \\
\text { ranking }\end{array}$ & $\begin{array}{l}\text { Initial teacher training } \\
\text { allocations: } 2014 \text { to } \\
2015 \text { (NCTL \& DfE } \\
\text { 2014) }\end{array}$ & $\begin{array}{l}\text { Shared } \\
\text { name/ } \\
\text { brandin } \\
\text { g }\end{array}$ \\
\hline $\begin{array}{l}\text { Birmingham City University } \\
\text { (Birmingham City University Academies Trust) }\end{array}$ & 3 & 88 & 637 & 8 \\
\hline $\begin{array}{l}\text { Canterbury Christ Church University } \\
\text { (Dover Christ Church Academy) }\end{array}$ & 3 & 106 & 1474 & \\
\hline $\begin{array}{l}\text { Staffordshire University } \\
\text { (Staffordshire University Academy Trust) }\end{array}$ & 3 & 103 & 127 & $\checkmark$ \\
\hline $\begin{array}{l}\text { Teeside University } \\
\text { (Teesside University Trust for Academies) }\end{array}$ & 3 & 98 & 0 & $\checkmark$ \\
\hline $\begin{array}{l}\text { University of the Creative Arts } \\
\text { (The Strood Academy) }\end{array}$ & 3 & 52 & 0 & \\
\hline $\begin{array}{l}\text { University of Bradford } \\
\text { (University Academy Keighley) }\end{array}$ & 3 & 63 & 0 & \\
\hline $\begin{array}{l}\text { University of Exeter } \\
\text { (The Ted Wragg Multiple Academy Trust) }\end{array}$ & 2 & 10 & 570 & \\
\hline $\begin{array}{l}\text { University of Hull } \\
\text { (the Thomas Ferens Academy) }\end{array}$ & 3 & 63 & 349 & \\
\hline $\begin{array}{l}\text { University of Kent } \\
\text { (The Brompton Academy) }\end{array}$ & 2 & 22 & 0 & \\
\hline $\begin{array}{l}\text { University of Lincoln } \\
\text { (Lincolnshire Educational Trust) }\end{array}$ & 3 & 51 & 0 & \\
\hline $\begin{array}{l}\text { University of Liverpool } \\
\text { (Northern Schools Trust) }\end{array}$ & 2 & 39 & 0 & \\
\hline $\begin{array}{l}\text { University of Nottingham } \\
\text { (Nottingham University Samworth Academy } \\
\text { Trust) }\end{array}$ & 2 & 25 & 439 & $\checkmark$ \\
\hline $\begin{array}{l}\text { University of Plymouth } \\
\text { (Marine Academy Trust) (Talent and Enterprise } \\
\text { Trust) }\end{array}$ & 3 & 90 & 451 & \\
\hline \multicolumn{5}{|l|}{$\begin{array}{l}\text { Universities whose engagement conforms with } \\
\text { Pattern } 2 \text { Average league table ranking = } 36\end{array}$} \\
\hline $\begin{array}{l}\text { Kings College London } \\
\text { ( King's College London Maths School Trust) }\end{array}$ & 2 & 23 & 267 & $\checkmark$ \\
\hline $\begin{array}{l}\text { University College London } \\
\text { (The UCL Academy) }\end{array}$ & 2 & 13 & 1546 & $\checkmark$ \\
\hline $\begin{array}{l}\text { University of Birmingham } \\
\text { (The University of Birmingham School) }\end{array}$ & 2 & 18 & 469 & $\checkmark$ \\
\hline $\begin{array}{l}\text { University of Cambridge (University of } \\
\text { Cambridge Training School) }\end{array}$ & 1 & 1 & 400 & $\checkmark$ \\
\hline $\begin{array}{l}\text { University of Exeter } \\
\text { (Exeter Mathematics School) }\end{array}$ & 2 & 10 & 570 & \\
\hline
\end{tabular}




\begin{tabular}{|c|c|c|c|c|}
\hline $\begin{array}{l}\text { University of Kingston } \\
\text { (The Kingston Education Trust) }\end{array}$ & 3 & 104 & 368 & \\
\hline $\begin{array}{l}\text { London South Bank University } \\
\text { (University Academy Of Engineering South } \\
\text { Bank) }\end{array}$ & 3 & 119 & 10 & \\
\hline \multicolumn{5}{|l|}{$\begin{array}{l}\text { Universities whose engagement conforms with } \\
\text { Pattern } 3 \text { Average league table ranking = } 77\end{array}$} \\
\hline $\begin{array}{l}\text { University of Brighton } \\
\text { (Hastings Academy Trust) }\end{array}$ & 3 & 76 & 785 & \\
\hline $\begin{array}{l}\text { University of Brighton } \\
\text { (University of Brighton Academy Trust) }\end{array}$ & 3 & 76 & 785 & $\checkmark$ \\
\hline $\begin{array}{l}\text { University of Chester } \\
\text { (University of Chester Academy Trust) }\end{array}$ & 3 & 93 & 622 & $\checkmark$ \\
\hline $\begin{array}{l}\text { University of Chichester } \\
\text { (University of Chichester Academy Trust) }\end{array}$ & 3 & 77 & 561 & $\checkmark$ \\
\hline $\begin{array}{l}\text { University of the West of England } \\
\text { (the Cabot Learning Federation) }\end{array}$ & 3 & 62 & 409 & \\
\hline $\begin{array}{l}\text { University of Wolverhampton } \\
\text { (Education Central Multi-Academy Trust) }\end{array}$ & 4 & Not listed & 435 & \\
\hline
\end{tabular}

None of the institutions engaged in pattern 3, and only four of the 13 institutions associated with pattern 1, but five of the seven associated with pattern 2, are in Boliver's (2015) top two status clusters. The third pattern of larger university sponsored MATs is exclusively associated with institutions in the third or fourth clusters. Institutions associated with pattern 2 and 3 are also more likely to have had significant numbers of initial teacher education (ITE) students.

\section{University sponsorship of academies and free schools in England: a discourse analysis}

The analysis of the website textual data identified four dominant discursive constructions of HEI sponsorship:

1. A discourse of 'social responsibility' which constructs sponsorship as inclusion, community engagement and community benefit;

2. A discourse of 'reputation', expressed with reference to pride, awards and plaudits, distinguished history, pedigree and influence and in which sponsorship both benefits from, and contributes to the institution's (both university and academy) reputation;

3. A discourse of 'distinctiveness', expressed in terms of sponsoring arrangements enabling a distinctive (and superior) educational offer;

4. A discourse of 'strategic development', in which sponsorship is expressed in terms of institutional response to the policy context.

Table 2. Instances of discursive constructions

\begin{tabular}{|c|c|c|c|c|c|c|}
\hline & \multirow[t]{2}{*}{ Institution } & \multirow[t]{2}{*}{ Source } & \multicolumn{4}{|c|}{ Instances of discursive constructions } \\
\hline & & & \begin{tabular}{|l|} 
1(social \\
responsibility
\end{tabular} & 2 (reputation) & $\begin{array}{l}3 \\
\text { (distinctive- } \\
\text { ness) }\end{array}$ & $\begin{array}{l}\text { (strategic } \\
\text { development) }\end{array}$ \\
\hline \multirow[t]{4}{*}{ Pattern1 } & \multirow{2}{*}{$\begin{array}{l}\text { Birmingham City University } \\
\text { (Birmingham City University } \\
\text { Academies Trust) }\end{array}$} & Trust /school website & 1 & & & 2 \\
\hline & & University website & 1 & 1 & & \\
\hline & \multirow{2}{*}{$\begin{array}{l}\text { Canterbury Christ Church } \\
\text { University }\end{array}$} & Trust/schools website & & 1 & 1 & \\
\hline & & University website & & & & \\
\hline
\end{tabular}




\begin{tabular}{|c|c|c|c|c|c|c|}
\hline \multicolumn{7}{|c|}{\begin{tabular}{|l|l} 
& (Dover Christ Church Academy) \\
\cline { 2 - 3 }
\end{tabular}} \\
\hline & \multirow{2}{*}{\begin{tabular}{|l|} 
Staffordshire University \\
(Staffordshire University \\
Academy Trust)
\end{tabular}} & Trust/school website & 4 & 7 & 2 & \\
\hline & & University website & 7 & & 10 & \\
\hline & \multirow{2}{*}{$\begin{array}{l}\text { Teeside University } \\
\text { (Teesside University Trust for } \\
\text { Academies) }\end{array}$} & Trust/school website & 1 & 2 & 2 & \\
\hline & & University website & 3 & 1 & 1 & 1 \\
\hline & \multirow{2}{*}{$\begin{array}{l}\text { University of Bradford } \\
\text { (University Academy Keighley) }\end{array}$} & Trust/school website & & & & \\
\hline & & University website & 4 & & 2 & 1 \\
\hline & \multirow{2}{*}{$\begin{array}{l}\text { University of the Creative Arts } \\
\text { (The Strood Academy) }\end{array}$} & Trust/school website & 1 & 3 & 3 & \\
\hline & & University website & 5 & & 3 & \\
\hline & \multirow{2}{*}{$\begin{array}{l}\text { University of Exeter } \\
\text { (Ted Wragg MAT) }\end{array}$} & Trust/school website & 5 & 1 & & \\
\hline & & University website & 2 & & 3 & \\
\hline & \multirow{2}{*}{$\begin{array}{l}\text { University of Hull } \\
\text { (The Thomas Ferens Academy) }\end{array}$} & Trust/school website & & 2 & 3 & \\
\hline & & University website & & 1 & & 1 \\
\hline & \multirow{2}{*}{$\begin{array}{l}\text { University of Kent } \\
\text { (The Brompton Academy) }\end{array}$} & Trust/school website & 1 & 2 & 6 & \\
\hline & & University website & 2 & 2 & & \\
\hline & \multirow{2}{*}{$\begin{array}{l}\text { University of Lincoln } \\
\text { (Lincolnshire Educational Trust) }\end{array}$} & Trust/school website & 7 & 2 & & 1 \\
\hline & & University website & & & & \\
\hline & \multirow{2}{*}{\begin{tabular}{|l|}
$\begin{array}{l}\text { University of Liverpool } \\
\text { (Northern Schools Trust) }\end{array}$ \\
\end{tabular}} & Trust/school website & & & & \\
\hline & & University website & 2 & & & \\
\hline & \multirow{2}{*}{$\begin{array}{l}\text { University of Nottingham } \\
\text { (Nottingham University } \\
\text { Samworth Academy Trust) } \\
\end{array}$} & Trust/school website & 5 & 1 & 5 & \\
\hline & & University website & 1 & 1 & 4 & \\
\hline & \multirow{2}{*}{\begin{tabular}{|l}
$\begin{array}{l}\text { University of Plymouth } \\
\text { (Marine Academy Trust) }\end{array}$ \\
\end{tabular}} & Trust/school website & 2 & 3 & 4 & \\
\hline & & University website & 1 & & & \\
\hline & \multirow{2}{*}{$\begin{array}{l}\text { University of Plymouth } \\
\text { (Talent and Enterprise Academy } \\
\text { Trust) }\end{array}$} & Trust/school website & & & 1 & \\
\hline & & University website & & & & \\
\hline & $\begin{array}{l}\text { Total number of instances } \\
\text { (average number of instances per } \\
\text { institution) }\end{array}$ & & $55(3.9)$ & $30(2.1)$ & $50(3.6)$ & $6(0.4)$ \\
\hline \multirow[t]{15}{*}{\begin{tabular}{|l} 
Pattern 2 \\
\end{tabular}} & \multirow{2}{*}{$\begin{array}{l}\text { Kings College London } \\
\text { (King's College London Maths } \\
\text { School Trust) }\end{array}$} & Trust/school website & 1 & 1 & 4 & \\
\hline & & University website & & & 5 & \\
\hline & \multirow{2}{*}{$\begin{array}{l}\text { University College London } \\
\text { (The UCL Academy) }\end{array}$} & Trust/school website & 3 & 3 & 4 & \\
\hline & & University website & 2 & 1 & 5 & 1 \\
\hline & \multirow{2}{*}{$\begin{array}{l}\text { University of Birmingham } \\
\text { (The University of Birmingham } \\
\text { School) }\end{array}$} & Trust/school website & 1 & 1 & 11 & \\
\hline & & University website & 3 & 6 & 1 & \\
\hline & \multirow{2}{*}{$\begin{array}{l}\text { University of Cambridge } \\
\text { (University of Cambridge } \\
\text { Training School) } \\
\end{array}$} & Trust/school website & & & 5 & 1 \\
\hline & & University website & 2 & 1 & 3 & 1 \\
\hline & \multirow{2}{*}{$\begin{array}{l}\text { University of Exeter } \\
\text { (Exeter Mathematics School) }\end{array}$} & Trust/school website & 5 & 3 & 6 & \\
\hline & & University website & 2 & & 1 & \\
\hline & \multirow{2}{*}{\begin{tabular}{|l|} 
University of Kingston \\
(The Kingston Education Trust)
\end{tabular}} & Trust/school website & 1 & 1 & 5 & \\
\hline & & University website & 2 & 1 & 1 & \\
\hline & \multirow{2}{*}{$\begin{array}{l}\text { London South Bank University } \\
\text { (University Academy Of } \\
\text { Engineering South Bank) } \\
\end{array}$} & Trust/school website & & 1 & 6 & 1 \\
\hline & & University website & 4 & & 4 & \\
\hline & $\begin{array}{l}\text { Total number of instances } \\
\text { (average number of instances per } \\
\text { institution) }\end{array}$ & & $26(3.7)$ & $19(2.7)$ & $61(8.7)$ & $4(0.6)$ \\
\hline \begin{tabular}{|l|} 
Pattern3 \\
\end{tabular} & University of Brighton & Trust/school website & 1 & 2 & 1 & \\
\hline & $\begin{array}{l}\text { (University of Brighton } \\
\text { Academy Trust) }\end{array}$ & University website & 8 & 5 & 8 & 1 \\
\hline & University of Brighton & Trust/school website & & 3 & & \\
\hline & (Hastings Academy Trust) & University website & 1 & 3 & & \\
\hline & University of Chester & Trust/school website & 2 & 1 & 2 & \\
\hline & $\begin{array}{l}\text { (University of Chester Academy } \\
\text { Trust) }\end{array}$ & University website & 3 & 1 & 2 & \\
\hline & University of Chichester & Trust/school website & 4 & 5 & & 2 \\
\hline & $\begin{array}{l}\text { (University of Chichester } \\
\text { Academy Trust) }\end{array}$ & University website & 1 & 1 & 1 & 1 \\
\hline & & Trust/school website & & & & \\
\hline
\end{tabular}




\begin{tabular}{|l|l|l|l|l|l|l|}
\hline & $\begin{array}{l}\text { University of the West of } \\
\text { England } \\
\text { (the Cabot Learning Federation) }\end{array}$ & University website & 3 & 6 & & \\
\hline $\begin{array}{l}\text { University of Wolverhampton } \\
\text { (Education Central Multi- } \\
\text { Academy Trust) }\end{array}$ & Trust/school website & 1 & 2 & 2 & 1 \\
\cline { 2 - 7 } & $\begin{array}{l}\text { Total number of instances } \\
\text { (average number of instances per } \\
\text { institution) }\end{array}$ & Total & 3 & 3 & 3 & 3 \\
\hline
\end{tabular}

Table 2 shows the number of instances of the different discourses in the website texts of HEIs and their trusts. It is notable that websites of institutions (and their trusts) sponsoring a single new academy (pattern 2) were much more likely to use the discourse of 'distinctiveness' than websites of institutions associated with either of the other patterns of engagement. By contrast, websites of institutions sponsoring larger MATs (pattern 3) were more likely to use the discourse of 'reputation' and 'strategic development'.

\section{Discourse of 'social responsibility'}

Common across the university sponsors, this discourse presents university sponsorship as partnership, with the academy/trust presented as the university's contribution, to the local community. For example:

'Firmly rooted in Sussex, we know our academies' local communities. This understanding helps us to support academies to work alongside parents and carers, other schools, colleges and businesses to create strong bonds for the benefit of all. (University of Brighton (a), undated)

This discourse often constructs sponsorship as a response to 'community need' for example, 'In 2010 the Schools Adjudicator gave the go ahead to the KET to establish a school in response to the significant need for fully inclusive secondary places in the local area' (Kingston University, 2015). It also often lays claim to raising aspirations and promoting social mobility and inclusiveness, for example: 'The trust partners share Ted Wragg's passion for education and the difference it can make to social mobility' (TWMAT, undated) and 'The School ... seeks to bring pupils together from different social and cultural backgrounds to create an environment that reflects the diversity of Birmingham and provides opportunities for everyone to excel' (University of Birmingham, 2017).

\section{Discourse of 'reputation'}

This discourse reflected the prestige of the sponsor onto the school/trust, for example '... the lead sponsor for Brompton academy is the prestigious university of Kent' (Brompton Academy, undated) and the sponsor's long history was often prominent as in, 'We are sponsored by LSBU, a technological university established over 120 years ago with a strong record of working with industry and employers' (University Academy of Engineering South Bank) as was the validation of its ITE 'our school of Education has been educating teachers for more than 100 years and has an "outstanding” Ofsted rating for its early primary and secondary initial teacher training' (University of Brighton (b), undated).

This discourse serves primarily to associate the school with the reputation of its sponsor but it can also serve to legitimate an entrepreneurial foray into a new area. 
... we have always been unafraid to take the lead and do things differently ... On the back of this success, I am proud and excited that our next 'first' is the opening of the University of Birmingham School. (University of Birmingham, 2017)

Sponsorship is also sometimes used to bolster the university's reputation, as in 'The Federation's success, and UWE Bristol's contribution to it, has twice been highlighted in Michael Gove's Academies Annual Reports to Parliament (2012 and 2013) as well as in other influential policy documents'. (University of the West of England, 2017)

\section{Discourse of 'distinctiveness'}

For schools sponsored by high status institutions, the 'brand' is an important asset serving to suggest the same excellent education for which the sponsor is renowned, 'KCL Maths School prepares students for degrees containing a high level of mathematics at the very best universities' (King's College London, Mathematics School, undated).

Access to expertise and research is a prominent part of this discourse in the two UTSs, for example 'A unique feature of the school will be the combination of primary education with a purpose-built research facility' (University of Cambridge Primary School, undated ) but was evident across most of the HEIs, 'The University ... will bring its experience of education and a successful record of working with academies to encourage innovation and transformational learning here too' (Dover Christ Church Academy, 2017).

Institutions also referred to access to university facilities and the role of university students; 'Examples of partnership activities include ... undergraduate 'Subject Tutors' supporting A Level lessons' (UCL Academy, undated) and a stated curriculum specialism also often features reflecting the identity of the sponsoring institution, for example,

Our partnership with the University has enabled us to create an exciting curriculum that is not only professionally orientated and employability focused, but it also fosters confidence and encourages enterprise. Our students will benefit from London South Bank University’s extensive employer links and specialist engineering facilities. (University Academy of Engineering, South Bank, 2014)

\section{Discourse of 'strategic development'}

A minority of institutions explicitly referred to institutional strategic aims, for example '[We will] build on the outstanding training already provided by the Faculty thereby enabling it to play a lead national role in the enhancement of teacher quality, student learning and strategies for school improvement' (University of Cambridge Academies Trust, 2017) and this was sometimes explicitly framed as a response to the policy context as in:

... to remain a leader in the field we need to adapt to the changes in government policy and the additional expectations placed upon us by Ofsted. The best universities are now expected to have direct rather than just indirect involvement in schools. (Birmingham City University Academies Trust, 2017)

and associated with an explicit institutional strategy,

Our strategic intention is to build a [MAT] of approximately thirty academies in hubs, geographically spread across our partnership area. (University of Chichester Academy Trust, 2017) 


\section{Discussion}

In making sense of patterns of engagement and discourse, it is useful to refer to the risks identified in the US literature as we can see the different patterns of engagement as institutional responses to the risks and opportunities presented by policy. With regard to opportunities, McGettigan (2014) has argued that cuts in LA funding and their withdrawal from the provision of services have opened up opportunities for 'third stream activities' as HEIs have become private providers of these services including schools. However, running academy schools is costly and funding is tight. Over 50 per cent of academies lack enough income to cover expenditure (Coughlan, 2017). University sponsors must balance the opportunities and risks and the different patterns of engagement by high and lower status institutions suggest that, for high status, wealthy institutions the balance often tips in favour of sponsorship of a single institution while less prestigious or lower cluster institutions may instead prioritise the economies of scale of larger MATs.

A risk that institutions have had to manage is falling initial teacher education (ITE) student numbers. In 2010 ITE became the target of a series of rapid, sweeping and influential policies which shunted provision from its 'traditional' university location towards schoolbased settings (McShane, 2016). The Government White Paper 'Educational Excellence Everywhere' (DfE, 2016c) and the recent announcement of 'teaching apprenticeships' (Whittaker, 2017) suggest school-led ITE will expand significantly with a consequent further undermining of university based routes. The proportion of institutions with significant ITE numbers amongst HEI sponsors since 2010 suggests maintaining a stake in initial teacher education (ITE) as a motivation.

Responses to such opportunities and risks are framed by a conception of the university as a business and a consideration of the website texts of universities and their trusts as 'discursive events' reveal them as examples of the marketization of HE and the 'colonization of discourse by promotion' identified by Fairclough (1993). University (and academy trust) websites are primarily promotional and the discursive constructions of sponsorship are shaped by and serve to contribute to this marketing and promotional function.

Although HEIs have been compelled to take on more and more the features and practices of business, the esteem in which they are held is in part a legacy of their historical independence of the financial motive and there was a shared silence in the website text on issues of financial benefit or risk. The 'business case' which would have been made in internal documents belongs to a different discursive practice.

There are significant reputational risks if academies do not perform well and the discursive practices of institutions can also be seen as discursive management of this risk. A number of universities have already been associated with their poorly performing academies including, for example, the UCL Academy (sponsored by the high status University College London) which was rated as 'requiring improvement' at its first inspection (Vaughan, 2014). In this context, the separation of the trust from the university name and brand may relate to minimising such reputational risk as may the recruitment of 'converter' academies (by definition schools that are performing well) to the larger MATs.

A third risk identified in the Charter School literature was that of 'misalignment with the university mission' and the discursive practices analysed in this study, reveal a reframing of the university mission in line with the fashioning of the university. The discursive constructions evident in the website texts coalesce around three metaphors of university sponsorship: 
- Sponsorship as philanthropy

- Sponsorship as 'brand building'

- Sponsorship as leadership of a local education 'hub'

Although universities as charitable bodies have a record of philanthropy which could be argued to predate the marketization of HE, philanthropy is consistent with current marketization in the form of 'corporate philanthropy' which has the potential to give competitive advantage (Porter \& Kramer, 2002). The other two metaphors are also consistent with the conception of universities as businesses and the strongly normalising presence of business entrepreneurialism in academy schools (Woods, Woods, \& Gunter, 2007) extends to their sponsorship by universities.

Importantly, the discursive function of university sponsorship reaches beyond the 'marketization' of/by institutions. The institutions' engagement and discursive construction of sponsorship legitimate the academies programme as something in which they, as respectable institutions with recognised educational credentials and probity, participate, thereby presenting participation in a contested policy as part of the university's mission to partner local councils and others 'to address the economic and social concerns of their local area' (Wade, 2017). Such legitimation carries potential costs - or 'pathological effects' (Fairclough, 1993, p. 142) - in terms of public trust.

In implementing schools' policy, staking and even building their own reputation on it, institutions' authority relations with the public and its capacity for disinterested academic critique of policy are called into question. The authenticity of claims of benefit to the local community and all its schools is problematic when the university has a privileged relationship with its own academies.

This legitimating function may explain the recent shift in policy from voluntarism to coercion in recent policy pronouncements. As the British Prime Minister has announced, '... the government will reform university fair access requirements and say that universities should actively strengthen state school attainment - by sponsoring a state school or setting up a new free school' (May, 2016).

The majority of HEIs in England have, to date, been reluctant to sponsor academies, with some rejecting outright the sponsoring of schools seeing it as a distraction from their core mission (Coughlan, 2016). Perhaps conscious of the risks involved, many have preferred instead to maintain partnership arrangements which make the expertise and research of the university a resource for all local schools and their staff and pupils, whether run by a LA or an Academy Trust (see for example the University of Oxford Education Deanery (Oxford University Department of Education, undated). The consequences of the majority of HEIs bowing to the pressure to sponsor schools could be a significant reframing of the mission of the university in terms of one (or more) of the three metaphors of sponsorship outlined in this paper and a silencing of academic critique and any such developments should be the focus of future research.

\section{References}

Andrews, J. (2016). School performance in multi-academy trusts and local authorities - 2015. London: Education Policy Institute.

Ball, S. J. (2007). Education plc: Understanding private sector participation in public sector education. London: Routledge. 
Basinger, J. (1999). Colleges experiment with charter schools. The Chronicle of Higher Education, 46(10), A51-A53.

Bayliss, C. (2016). 'Our LA is quite "hands-off”' anyway, so what freedoms would academy conversion bring?’ Schools Week. Retrieved from http://schoolsweek.co.uk/our-la-is-quite-hands-off-anywayso-what-freedoms-would-academy-conversion-bring/

Bergeron, B. S. (2015). Visioning hope: Embracing Higher Education’s role with urban public charter schools. Urban Education, 1-27. doi:10.1177/0042085915574525.

Birmingham City University (2017). Rationale for the establishment of BCUAT. Retrieved from http://www.bcu.ac.uk/bcuat

Boffey, D. (2015). Claims of 'irregularities’ at free schools and academies. The Observer, 5 September. Retrieved from https://www.theguardian.com/education/2015/sep/05/free-schools-academies-callfor-checks-as-fraud-allegations-mount

Boffey, D., \& Mansell, W. (2016). Are England's academies becoming a cash cow for business? The Observer, 12 June. Retrieved from https://www.theguardian.com/education/2016/jun/12/academyschools-cash-cow-business

Boliver, V. (2015). Are there distinctive clusters of higher and lower status universities in the UK? Oxford Review of Education, 41(5), 608-627. doi:10.1080/03054985.2015.1082905.

Brompton Academy (undated). Lead Sponsor University of Kent. Retrieved from http://www.bromptonacademy.org.uk/30/lead-sponsor-university-of-kent

Burke, J. (2017) Michael Gove: UTCs have failed. Schools Week. Retrieved from http://schoolsweek.co.uk/michael-gove-utcs-have-failed/

Collini, S. (2010). Brown's Gamble. London Review of Books, 32(21), 23-25.

Coughlan, S. (2016). Oxford head rejects sponsoring schools. Retrieved from http://www.bbc.co.uk/news/education-37440546

Coughlan, S. (2017) Half of academies fall short on funding. Retrieved from http://www.bbc.co.uk/news/education-38809574

Department for Children, Schools and Families (DCSF) \& Department for Innovation, Universities, and Skills (DIUS). (2007). Academies, Trusts and Higher Education: Prospectus. Retrieved from http://dera.ioe.ac.uk/9211/2/AcademiesTrustProspectus_Redacted.pdf

Department for Education (DfE). (2010). The importance of teaching. Cm 7980. London: DfE.

DfE (2016a). Multi-academy trusts: Good practice guidance and expectations for growth. Retrieved from https://www.gov.uk/government/uploads/system/uploads/attachment_data/file/576240/Multiacademy_trusts_good_practice_guidance_and_expectations_for_growth.pdf

DfE (2016b). Open academies and academy projects in development. Retrieved from https://www.gov.uk/government/publications/open-academies-and-academy-projects-indevelopment

DfE (2016c). Educational excellence everywhere. Cm 9230. London: DfE.

Dover Christ Church Academy (2017). 'Our sponsors.’ Retrieved from http://www.dccacademy.org.uk/aboutus/our_sponsors.php

Eckes, S. E., \& Plucker, J. A. (2013). Segregation in Charter Schools: The Important Role of University-Based Authorizers. Education and Urban Society, 45(5 ), 589-608. doi:10.1177/0013124513486291

Edmond, N. (2017). Beyond 'Entrepreneurialism of the Self': What it Means to be a Student in the Neoliberal University. In T. Rudd \& I. Goodson (Eds.), Negotiating Neoliberalism: Developing Alternative Educational Visions (pp. 71-85). Rotterdam: Sense. 
Fairclough, N. (1993). Critical discourse analysis and the marketisation of public discourse: the universities. Discourse \& Society, 4(2), 133-168.

Ferlie, E., Lynn, L. E., \& Pollitt, C. (Eds.). (2005). The Oxford Handbook of Public Management. Oxford: Oxford University Press.

Finn, C. E., Ryan, T., \& Lafferty, M. (2010). Ohio's education reform challenges: Lessons from the frontlines. New York, NY: Palgrave Macmillan.

Gillard, D. (2011). Education in England: a brief history. Retrieved from www.educationengland.org.uk/history

Gorard, S. (2011). Are Academies Working? In H. M. Gunter (Ed.), The State and Education Policy: The Academies Programme (pp.120-132). London: Continuum.

Gunter, H. M. (Ed.) (2011). The State and Education Policy: The Acacdemies Programme. London: Continuum.

Hatcher, R. (2011). Local government against local democracy: A case study of a bid for building schools for the future funding for an academy. In $\mathrm{H}$. Gunter (Ed.), The state and education policy: The Academies Programme (pp. 39-52). London: Continuum.

Helm, T., \& Lightfoot, L. (2007). Another blow for Blair's legacy as schools shun trust plan. The Telegraph. Retrieved from http://www.telegraph.co.uk/news/uknews/1541624/Another-blow-forBlairs-legacy-as-schools-shun-trust-plan.html

Higher Education Funding Council for England (HEFCE). (2016). Schools sponsored by higher education providers. Retrieved from http://www.hefce.ac.uk/workprovide/schools/

Jessop, B. (2017). Varieties of academic capitalism and entrepreneurial universities. Higher Education, 1-18. doi:10.1007/s10734-017-0120-6

Kennedy, R. (2016). 'Lab schools.' Retrieved from http://www.privateschoolreview.com/blog/labschools

King’s College London (undated). 'King's Maths School.’ Retrieved from http://www.kcl.ac.uk/aboutkings/strategy/profiles/Kings-Maths-School.aspx

Kingston University (2015). The Kingston Academy's first crop of students meet up at Kingston University event. Retrieved from http://www.kingston.ac.uk/news/article/1525/09-jul-2015-thekingston-academys-first-crop-of-students-meet-up-at-kingston-university-event/

Lindstrom, N. (2014). Senate could vote soon on charter school plan. Retrieved from https://www.edreform.com/2014/01/senate-could-vote-soon-on-charter-school-plan/

Lipsett, A. (2007). What are academy sschools? The Guardian Education, November 13. Retrieved from http://www.theguardian.com/education/2007/nov/13/newschools.schools

Mansell, W., \& Johnson, M. (2014). Education not for sale: A TUC research report. London: Trades Union Congress.

May, T. (2016) Britain, the great meritocracy. Speech to the British Academy, 9 September 2016. Retrieved from https://www.gov.uk/government/speeches/britain-the-great-meritocracy-primeministers-speech

McGettigan, A. (2014). The third mission and beyond: University activities in the new market terrain. Retrieved from https://blogs.staffs.ac.uk/mikehamlyn/2014/12/

McShane, J. (2016). Out of step? Reflections on the changing role of universities in Initial Teacher Training since 2010. The BERA Blog: Research Matters. Retrieved from https://www.bera.ac.uk/blog/out-of-step-reflections-on-the-changing-role-of-universities-in-initialteacher-training-since-2010

Natale, S. M., Libertella, A. F., \& Hayward, G. (2001). Higher education in crisis: The corporate eclipse of the university. Binghampton, NY: Global Publications Binghampton University. 
National Association of Charter School Authorizers (NACSA). (2016). Authorizing data in depth: Authorizer demographics. Retrieved from http://www.qualitycharters.org/researchpolicies/archive/soca-data-in-depth-authorizer-demographics/

OECD. (2010). Strong performers and successful reformers in education: Lessons from PISA for the United States. Retrieved from http://www.oecd-ilibrary.org/education/lessons-from-pisa-for-theunited-states_9789264096660-en

Office for Standards in Education (2015). School inspection handbook - Section 8. London: The Office for Standards in Education, Children's Services and Skills (Ofsted).

Oxford University Department of Education. (Undated). The Oxford Education Deanery. Retrieved from http://www.education.ox.ac.uk/about-us/the-oxford-education-deanery/

Porter, M. E., \& Kramer, M. R. (2002). The competitive advantage of corporate philanthropy. Harvard Business Review (December 2002).

Plucker, J. A., Simmons, A. B., Eckes, S. E., Rapp, K. E., Benton, S. A., \& Nowak, J. (2004). University sponsorship of charter schools in Indiana. Bloomington, IN: Centre for Evaluation and Education Policy.

Ravitch, D. (2010). The myth of charter schools. The New York Review of Books.

Ravitch, D. (2014). Reign of error: The hoax of the privatization movement and the danger to America's public schools. New York: Vintage Books.

Ravitch, D. (2016). The death and life of the great American school system: How testing and choice are undermining education. New York: Basic Books.

Reckhow, S., Grossman, M., \& Evans, B. C. (2015). Policy cues and ideology in attitudes toward charter schools. Policy Studies Journal, 43(2), 207-227. doi:10.1111/psj.12093

Robbins, L. (1963). Higher education report of the Committee appointed by the Prime Minister under the chairmanship of Lord Robbins, 1961-1963. London: HMSO.

Rogers, R., Schaenen, I., Schott, C., O’Brien, K., Trigos-Carrillo, L., Starkey, K., \& Chasteen, C. C. (2016). Critical discourse analysis in education: A review of the literature, 2004 to 2012. Review of Educational Research, 86(4), 1192-1226.

Saichaie, K., \& Morphew, C. C. (2014). What college and university websites reveal about the purposes of higher education. The Journal of Higher Education, 85(4), 499-530.

Shen, Y. (2011). Authorizing charter schools. Retrieved from http://www.ncsl.org/documents/educ/AuthorizingCharterSchools.pdf

Shore, C., \& McLauchlan, L. (2012). Third mission' activities, commercialisation and academic entrepreneurs. Social Anthropology, 20(3), 267-286.

Ted Wragg Multi Academy Trust (TWMAT). (Undated). Retrieved from https://www.cranbrookeducationcampus.org.uk/about-us/twmat/

University Academy of Engineering (UAE) Southbank (2014). Prospectus. Retrieved from http://www.uaesouthbank.org.uk/uploads/Academy\%20Calendar/University_Academy_of_Engine ering_Prospectus.pdf

University College London (UCL). (Undated). Education partnerships. Retrieved from https://www.ucl.ac.uk/teaching-learning/education-initiatives/education-partnerships

University of Birmingham (2017). University of Birmingham School. Retrieved from http://www.birmingham.ac.uk/university/university-school/index.aspx

University of Brighton (a) (Undated). Our vision: Communities. Retrieved from https://www.brighton.ac.uk/academiestrust/our-vision/communities/index.aspx

University of Brighton (b) (Undated). University of Brighton Academy Trust. Retrieved from https://www.brighton.ac.uk/academiestrust/index.aspx 
University of Cambridge Academies Trust (2017), University of Cambridge Training School to provide primary education in North West Cambridge. Retrieved from

https://www.cam.ac.uk/news/university-of-cambridge-training-school-to-provide-primaryeducation-in-north-west-cambridge

University of Cambridge Primary School (undated). Parent Information. Retrieved from http://universityprimaryschool.org.uk/parent-information/

University of Chichester Academy Trust (2017). Our multi-academy trust. Retrieved from http://www.unicat.org.uk/our-multi-academy-trust

University of the West of England (2017). Improving young people's engagement with education. Retrieved from http://www1.uwe.ac.uk/research/researchimpact/engagementwitheducation.aspx

Uzuner-Smith, S., \& Englander, K. (2015). Exposing ideology within university policies: A critical discourse analysis of faculty hiring, promotion and remuneration practices. Journal of Education Policy, 30(1), 62-85.

Vaughan, R. (2014). University schools told to improve. The Times Higher Education. Retrieved from https://www.timeshighereducation.com/news/university-schools-told-to-improve/2014329.article

Wade, G. (2017). Acting locally: Universities reconnecting with communities. Retrieved from http://www.universitiesuk.ac.uk/blog/Pages/Acting-locally-universities-reconnecting-withcommunities.aspx

Wakeling, P., \& Savage, M. (2015). Entry to elite positions and the stratification of higher education in Britain. The Sociological Review, 63, 290-320. doi: 10.1111/1467-954X.12284.

Weal, S. (2017). £9m Greater Manchester college closes after three years due to lack of pupils. The Guardian. Retrieved from https://www.theguardian.com/education/2017/feb/07/greatermanchester-university-technical-college-closes-three-years

West, A., \& Bailey, E. (2013). The development of the academies programme: 'Privatising' schoolbased education in England, 1986-2013. The British Journal of Educational Studies, 61(2), 137159. doi:10.1080/00071005.2013.789480.

Whittaker, F. (2017). Teaching apprenticeships: the new school direct? Schools Week. Retrieved from http://schoolsweek.co.uk/teaching-apprenticeships-the-new-school-direct/

Woods, P. A., Woods, G. J., \& Gunter, H. (2007). Academy schools and entrepreneurialism in education. Journal of Education Policy, 22(2), 237-259.

\section{Notes}

i The national curriculum is a set of subjects and standards used by primary and secondary schools so children learn the same things. Academies must teach a broad and balanced curriculum including English, maths and science. They must also teach religious education.

ii The Report of the Committee on Higher Education chaired by Lord Robbins explicitly identified four purposes for HE: instruction in skills 'suitable to play a part in the general division of labour', the promotion of the general powers of the mind, the advancement of learning, the transmission of a common culture, and common standards of citizenship.

iii This latter requirement has since been removed from all sponsors. 